\title{
WOCE PACIFIC OCEAN RADIOCARBON PROGRAM
}

\author{
ROBERT M. KEY \\ Ocean Tracer Laboratory, Atmospheric and Oceanic Sciences Program, Department of Geosciences, \\ Princeton University, Princeton, New Jersey 08610 USA
}

\begin{abstract}
Fieldwork for the World Ocean Circulation Experiment (WOCE) radiocarbon program was recently completed. $\mathrm{Ca} .9000$ samples were collected for analysis using both conventional $\beta$-counting techniques and the newer AMS technique. The mean uncertainty for the $\beta$ analyses is $3 \%$; for AMS analyses, ca. $4.5 \%$.
\end{abstract}

\section{INTRODUCTION}

The World Ocean Circulation Experiment (WOCE) has been an unprecedented effort to study largescale ocean circulation, with fieldwork by scientists from more than 30 countries making many thousands of measurements. The overall goal of the program is to obtain a detailed description of the physical properties and circulation of the global ocean. These data will be used to determine the role of ocean circulation in global climate change and to help develop models that can be used to predict those changes.

A major component of WOCE was the "one-time survey". This phase of the fieldwork was conducted along both zonal and meridional hydrographic lines, on which stations were occupied with a nominal horizontal spacing of 30 nautical miles $\left(\sim 56 \mathrm{~km}\right.$, or $\sim 0.5^{\circ}$ latitude or longitude). At each station, discrete water samples (small-volume samples (SV)) were collected over the entire water column using a CTD equipped with a 24- to 36-place Rosette sampler. At some of the stations in the Pacific, the deep and bottom waters also were sampled using 250-liter stainless steel Gerard barrels to collect large-volume (LV) samples. Each small-volume sample was measured for pressure, temperature, salinity, oxygen, nitrate, nitrite, silicate and phosphate. Significant subsets of the SV samples were measured for chlorofluorocarbons, ${ }^{3} \mathrm{H},{ }^{3} \mathrm{He},{ }^{13} \mathrm{C}$ and ${ }^{14} \mathrm{C}$. Through a collaborative effort with the Joint Global Ocean Flux Study (JGOFS) many of the SV samples were also measured for carbon species (generally $\mathrm{TCO}_{2}$ and alkalinity). Pressure, temperature, salinity, silicate and ${ }^{14} \mathrm{C}$ were measured on all of the LV samples.

This paper gives an overview of the U.S. WOCE radiocarbon measurement program for the Pacific Ocean. All of the planned U.S. Pacific Ocean fieldwork has been completed. Table 1 summarizes the legs that were sampled for ${ }^{14} \mathrm{C}$. For each entry, the table lists the cruise leg, the common cruise name (AKA, "also known as") and the official WOCE designation, the chief scientist for that leg, the dates of the cruise, the principal investigator (PI) responsible for ${ }^{14} \mathrm{C}$ collection and interpretation and the lab(s) responsible for the actual sample measurements. The Pacific Ocean stations that were sampled for ${ }^{14} \mathrm{C}$ are shown in Figure 1. Over 9000 samples were collected for ${ }^{14} \mathrm{C}$ analysis during this effort. Some of the apparent gaps in Figure 1 were filled by the sampling programs of other countries (primarily Australia, New Zealand and Japan). Some of the early results from these measurements are presented in this issue (Key et al. 1996; Stuiver et al. 1996).

\section{METHODS}

The goal of the WOCE Pacific radiocarbon program was to generate a data set of sufficient density and precision that the distribution could be described with reasonable accuracy in three dimensions. The GEOSECS survey of the Pacific deep and bottom waters (depths $>\sim 1000 \mathrm{~m}$ ) clearly demonstrated that the meridional $\Delta^{14} \mathrm{C}$ gradients were small (Östlund and Stuiver 1980). While no zonal 


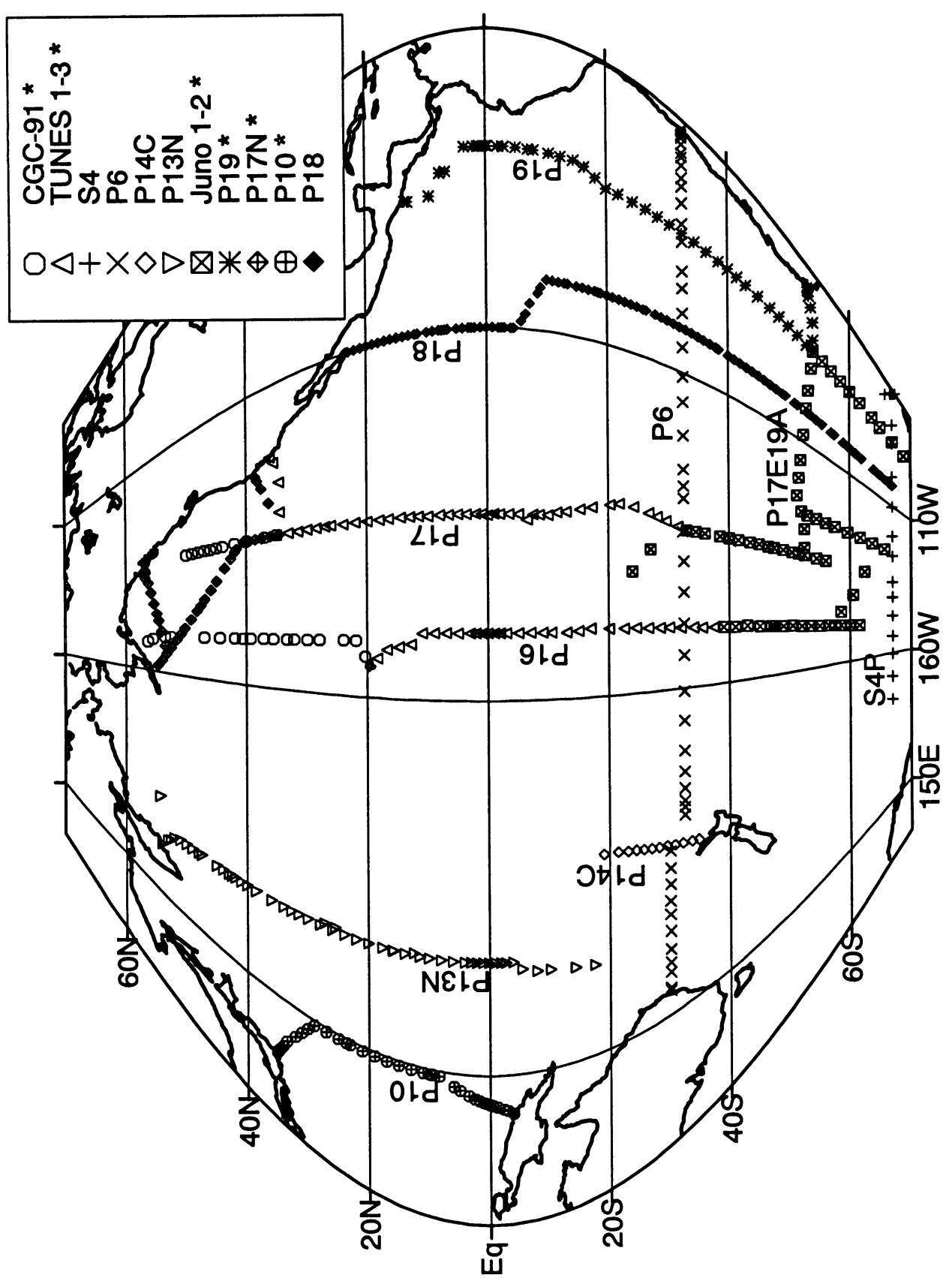

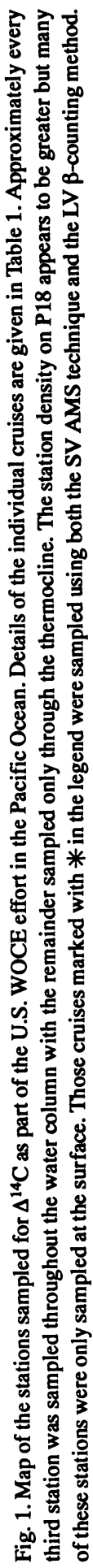


TABLE 1. WOCE Pacific Cruise Summary

\begin{tabular}{|c|c|c|c|c|c|}
\hline Cruise & $\begin{array}{l}\text { AKA } \\
\text { WOCE name }\end{array}$ & Chief scientist & Cruise dates & ${ }^{14} \mathrm{C}$ PI & $\begin{array}{l}\text { Analytical lab } \\
\text { AMS }^{*} / \mathrm{LV}-\beta \dagger\end{array}$ \\
\hline P17Nł & $\begin{array}{l}\text { CGC-91 Leg } 1 \\
\text { 31DSCGC91/1 }\end{array}$ & D.Weisgarver & $2 / 16-2 / 28 / 1991$ & R. Key & $\begin{array}{l}\text { NOSAMS } 1 \\
\text { M. Stuiver }\end{array}$ \\
\hline P16N & $\begin{array}{l}\text { CGC-91 Leg } 2 \\
\text { 31DSCGC91/2 }\end{array}$ & J. Bullister & $3 / 7-4 / 8 / 1991$ & R. Key & $\begin{array}{l}\text { NOSAMS } \\
\text { G. Östlund } \\
\text { M. Stuiver }\end{array}$ \\
\hline P17C & $\begin{array}{l}\text { TUNES-1 } \\
\text { 31WTTUNES/1 }\end{array}$ & M. Tsuchiya & $5 / 31-7 / 11 / 1991$ & R. Key & $\begin{array}{l}\text { NOSAMS }^{5} \\
\text { G. Östlund }\end{array}$ \\
\hline P16S17S & $\begin{array}{l}\text { TUNES-2 } \\
\text { 31WTTUNES/2 }\end{array}$ & J. Swift & $7 / 16-8 / 25 / 1991$ & R. Key & $\begin{array}{l}\text { NOSAMS } \\
\text { G. Östlund } \\
\text { M. Stuiver }\end{array}$ \\
\hline P16C & $\begin{array}{l}\text { TUNES-3 } \\
\text { 31WTTUNES/3 }\end{array}$ & L. Talley & $8 / 31-10 / 1 / 1991$ & P. Quay & $\begin{array}{l}\text { NOSAMS }^{10} \\
\text { M. Stuiver }\end{array}$ \\
\hline S4P & RUKDIOFFE6/1 & Koshlyakov & $2 / 14-4 / 6 / 1992$ & P. Schlosser & NOSAMS \\
\hline P6E & 316 N138/3 & H. Bryden & $5 / 2-5 / 26 / 1992$ & R. Key & NOSAMS $^{12}$ \\
\hline P6C & 316 N138/4 & M. McCartney & $5 / 30-6 / 7 / 1992$ & R. Key & NOSAMS $^{13}$ \\
\hline P6W & $316 N 138 / 4$ & J. Toole & $6 / 13-6 / 30 / 92$ & R. Key & NOSAMS ${ }^{14}$ \\
\hline P14C & 316 N138/7 & D. Roemmich & $9 / 1-9 / 15 / 1992$ & R. Key & NOSAMS \\
\hline P13N & $\begin{array}{l}\text { CGC-92 Leg } 1 \\
\text { 3220CGC92/1 }\end{array}$ & J. Bullister & $8 / 3-9 / 10 / 1992$ & P. Quay & NOSAMS \\
\hline P16A17A & $\begin{array}{l}\text { Juno-1 } \\
\text { 316N138/9 }\end{array}$ & J. Reid & $10 / 6-11 / 26 / 1992$ & R. Key & $\begin{array}{l}\text { NOSAMS }^{15} \\
\text { G. Östlund } \\
16\end{array}$ \\
\hline P17E19A & $\begin{array}{l}\text { Juno-2 } \\
\text { 316N138/10 }\end{array}$ & J. Swift & $12 / 4 / 92-1 / 22 / 1993$ & R. Key & $\begin{array}{l}\text { NOSAMS } \\
\text { G. Östlund }{ }^{17}\end{array}$ \\
\hline P19C & $316 \mathrm{~N} 138 / 12$ & L. Talley & $2 / 22-4 / 13 / 1993$ & R. Key & $\begin{array}{l}\text { NOSAMS } \\
\text { G. Östlund }{ }^{18}\end{array}$ \\
\hline P17N & $325021 / 1$ & D. Musgrave & $5 / 15-6 / 26 / 1993$ & $\begin{array}{l}\text { P. Quay } \\
\text { R. Key }\end{array}$ & $\begin{array}{l}\text { NOSAMS } \\
\text { M. Stuiver }\end{array}$ \\
\hline P10 & 3250 TN026/1 & M. Hall & $10 / 5-11 / 10 / 1993$ & R. Key & $\begin{array}{l}\text { NOSAMS } \\
\text { M. Stuiver }\end{array}$ \\
\hline P18S & 31DSCGC $94 / 2$ & B. Taft & $2 / 22-3 / 2 / 1994$ & P. Quay & NOSAMS \\
\hline P18N & 31DSCGC $94 / 3$ & G. Johnson & $3 / 27-4 / 27 / 1994$ & P. Quay & NOSAMS \\
\hline
\end{tabular}

"NOSAMS determined $\delta^{13} \mathrm{C}$ for all $\mathrm{AMS}^{14} \mathrm{C}$ measurements except for legs on which P. Quay was PI.

$\dagger \mathrm{M}$. Stuiver determined $\delta^{13} \mathrm{C}$ for all LV samples

¥Not an official WOCE cruise

${ }^{1}$ NOSAMS 1994a; ${ }^{2}$ NOSAMS 1994a; ${ }^{3}$ Östlund 1992a; ${ }^{4}$ Stuiver 1994; ${ }^{5}$ NOSAMS 1994c; ${ }^{6}$ Östlund 1992b, 1994; ${ }^{7}$ NOSAMS 1995a, 1996; ${ }^{8}$ Östlund 1994, 1995; ${ }^{9}$ Stuiver 1994; ${ }^{10}$ NOSAMS 1996; ${ }^{11}$ Stuiver 1994; ${ }^{12}$ NOSAMS 1995b; ${ }^{13}$ NOSAMS 1994b; ${ }^{14}$ NOSAMS 1995b; ${ }^{15}$ NOSAMS 1995c; ${ }^{16}$ Östlund 1995; ${ }^{17}$ Östlund 1994, 1995; ${ }^{18}$ Östlund 1994, 1995

section was collected during GEOSECS, the data were sufficient to indicate that deep zonal $\Delta^{14} \mathrm{C}$ gradients would be even smaller.

During the planning phase of WOCE, the accelerator mass spectrometry (AMS) technique for measuring ${ }^{14} \mathrm{C}$ was still relatively new in the United States. The general procedures had been worked out, but no lab was prepared to handle the large number of samples expected from the WOCE program, 
nor had it been demonstrated that the AMS technique could deliver the required precision on a routine basis. The National Ocean Sciences AMS Facility (NOSAMS) at Woods Hole Oceanographic Institution was established in 1989 to serve this purpose. In planning the WOCE Pacific fieldwork, it was recognized that sample collection would begin well before NOSAMS could deliver the high precision offered by conventional $\beta$-counting techniques. Therefore, both techniques were utilized.

On those legs which included both LV and SV sampling, the LV stations were spaced at an average interval of $5^{\circ}(\sim 300$ nautical miles $=\sim 555 \mathrm{~km})$. LV stations normally included two casts of nine Gerard barrels each covering the water column from $\sim 1000 \mathrm{~m}$ to the bottom. The upper kilometer of a LV station was covered by $16 \mathrm{SV}$ samples taken from the CTD/Rosette cast. The legs that included both sample types are the ones that have more than one entry in the rightmost column of Table 1 and are indicated in Figure 1 by a $*$ in the legend. One to three SV stations were placed between each LV station. On SV stations only the upper thermocline region was sampled, using $16 \mathrm{SV}$ samples.

${ }^{14} \mathrm{C}$ was extracted from the $\mathrm{LV}$ samples at sea as ${ }^{14} \mathrm{CO}_{2}$, absorbed on excess $\mathrm{NaOH}$ and returned to shore in well-sealed glass bottles using a modification of the technique described by Fonselius and Östlund (1959) (Key 1991; Key et al. 1991). Once ashore, the samples were sent to one of two labs for analysis: Tritium Laboratory, University of Miami, Miami, Florida (G. Östlund, director); or Quaternary Isotope Laboratory, University of Washington, Seattle (M. Stuiver, director). A short description of the measurement procedure and a cross-check between these two labs is available in Stuiver et al. (1974). Stuiver reports an error estimate for each analysis ranging from 2.5 to $4.0 \%$; Östlund reports a uniform sample error of $4 \%$. In both cases, the reported uncertainty is primarily counting error and does not include any error due to sample collection. All $\delta^{13} \mathrm{C}$ measurements for the LV samples were made by Stuiver.

All SV ${ }^{14} \mathrm{C}$ samples were collected from standard CTD/Rosette casts into 500-ml glass bottles fitted with high-quality ground glass stoppers. The samples were poisoned with $\mathrm{HgCl}_{2}$ immediately after collection, then returned to the U.S. for extraction and analysis at NOSAMS. Details of the extraction, counting, etc. are available from Key (1991), McNichol and Jones (1991), Gagnon and Jones (1993), Cohen et al. (1994), McNichol et al. (1994), Osborne et al. (1994), Schneider et al. (1994) and Séguin et al. (1994). All $\delta^{13} \mathrm{C}$ analyses, except for the samples collected by Quay (who extracted and measured his own $\delta^{13} \mathrm{C}$ values), were performed at NOSAMS.

The standards for the ${ }^{14} \mathrm{C}$ measurements were NBS oxalic acid standards (Östlund, RM 49 and SRM 4990C; Stuiver, RM 49 and SRM 4990C; NOSAMS, SRM 4990 and SRM 4990C). All results are reported as $\Delta^{14} \mathrm{C}$, which is the deviation in per mil (\%o) from unity of the sample to standard activity ratio, isotope-corrected to a sample $\delta^{13} \mathrm{C}$ value of $-25 \%$. (For more information on standards and calculation methods, see Broecker and Olson (1961), Stuiver and Robinson (1974) and Stuiver (1980).) As measurements were completed, the results were communicated from the analytical lab to the PI responsible for the cruise via periodic data reports (see footnotes to Table 1). R. Key gathered the $\Delta^{14} \mathrm{C}$ data from the $\mathrm{PI}$, merged it with hydrographic data supplied either by the chief scientist or by the WOCE Hydrographic Office (WHPO), added WOCE quality-control flags, and finally submitted the data to WHPO along with a final report for each leg (Key 1994, 1995, 1996a-i; Key and Quay 1996). All of the LV samples collected in the Pacific will be completed by 1997 and the Pacific SV samples by 1998.

\section{DATA QUALITY}

The precision of the LV technique was established during the GEOSECS program to be $2-4 \%$. This precision is primarily a function of sample counting time and has held constant throughout the succeeding large-scale ocean survey programs. What was unknown at the beginning of WOCE was the 
ultimate precision of the AMS technique and whether or not the AMS and LV data would be totally compatible, i.e., no systematic errors would be found in either data set.

NOSAMS is currently running water samples with a mean "external" precision of 3.6\%o. This precision is indicative of the AMS target preparation and counting and does not include any uncertainty due to sample collection, storage or stripping. A better estimate of the sample precision can be obtained by comparing the results from duplicate samples. A summary all of the true WOCE duplicates (i.e., two different sample bottles rather than two analyses from the same bottle) analyzed at NOSAMS showed that the average of the standard deviation for each pair was $4.6 \%$. The reason for the difference between this number and the external precision estimate $(3.6 \%)$ is currently unknown, but must involve either sample collection or sample processing prior to counting. A reproducibility of 3\%o is needed for the AMS technique to be equivalent to the average uncertainty for the LV technique. Sample storage experiments at NOSAMS and other facilities have so far indicated that this is not a source of error.

Once all of the Pacific samples are completed, sufficient data will exist to make statistically significant comparisons between AMS and LV sampling. For now, the best that can be done is to graphically compare WOCE stations where the two techniques overlap, and to compare WOCE results in deepwater to GEOSECS results. Figure 2 shows results from TUNES-2 (P16S17S) station 179, Juno-1 (P16A17A) station 119 and P6C station 100 taken at $c a .33^{\circ} \mathrm{S}, 135^{\circ} \mathrm{W}$. The TUNES station includes both LV and SV samples and was occupied on 7/1991. Stuiver analyzed the LV samples from this station. The Juno occupation was on 11/1992 at the same location as the TUNES station. Östlund measured the LV samples from Juno-1. The P6 station was ca. 250 nautical miles away (463 $\mathrm{km}$ ) and was occupied on 7/1992. Each datum is shown with 2-o error bars. At this scale, the agreement between the techniques appears to be good. The only possible systematic difference is in the upper thermocline, with the TUNES samples being slightly lower than those from Juno and P6. This apparent offset may be due to a real difference in the water column structure. A better place to compare the results is in the deepwater. The insert in the lower right portion of Figure 2 shows the data from the bottom $2 \mathrm{~km}$ on a greatly expanded scale. The pressure scale for the insert is aligned and scaled to match the pressure scale of the main figure. There is some structure in the $\Delta^{14} \mathrm{C}$ signal, but there is no apparent systematic difference between the measurement techniques. This plot clearly demonstrates the need for very high-precision data in the deep and bottom waters.

Another data test can be made by comparing the new AMS data to existing historical data. Figure 3 shows a plot of WOCE P6 station $148\left(32.5^{\circ} \mathrm{S}, 163.6^{\circ} \mathrm{W} ; 6 / 1992\right)$ AMS results (NOSAMS 1994b) with GEOSECS station $306\left(32.5^{\circ} \mathrm{S}, 165.2^{\circ} \mathrm{W} ; 3 / 1974\right) \mathrm{LV}$ results (Östlund and Stuiver 1980). The invasion of bomb ${ }^{14} \mathrm{C}$ into the thermocline is clearly evident. The deep- and bottom-water data are shown on an expanded scale in the insert in the lower right portion of the figure. The deepwater data $(2500-4500 \mathrm{~m})$ from the two stations appear to be the same. Below $4500 \mathrm{~m}$ the AMS $\Delta^{14} \mathrm{C}$ results are slightly higher than the GEOSECS results. At this point it is difficult to determine if this difference is a measurement difference or a small bomb-produced ${ }^{14} \mathrm{C}$ signal that has been introduced into the bottom waters since the time of GEOSECS. The meaning of differences this small will require a careful statistical analysis of the full WOCE data set.

\section{Conclusion}

The Pacific Ocean WOCE program has generated a new high-quality data set for analyzing the distribution of ${ }^{14} \mathrm{C}$. Comparison using currently available data indicates that measurements using the 


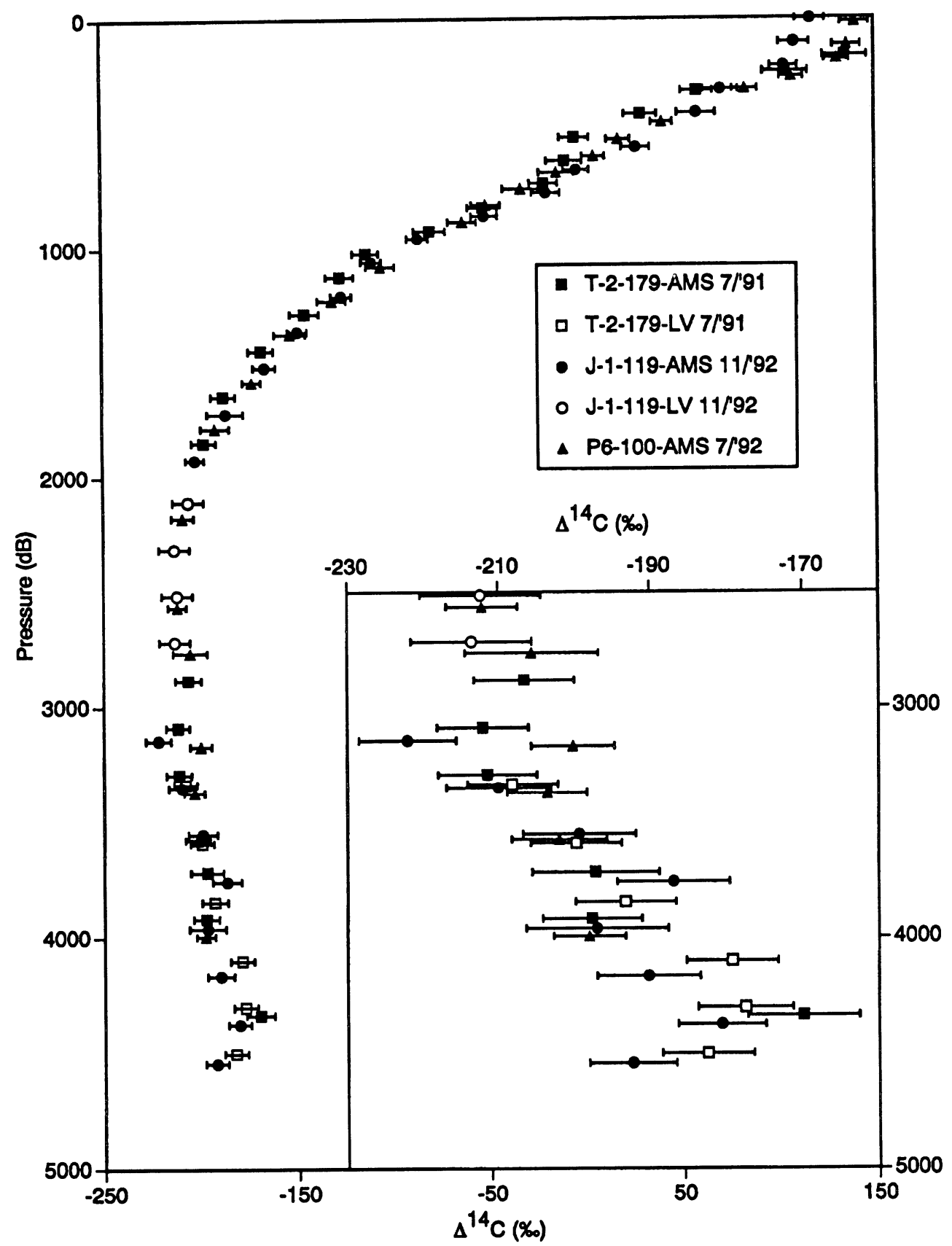

Fig. 2. Comparison of AMS and LV results for three stations in the south-central Pacific Ocean. The TUNES-2 station 179 data and the Juno-1 station 119 data were collected at the same location $\left(33^{\circ} \mathrm{S}, 135^{\circ} \mathrm{W}\right)$, but 14 months apart $(7 / 1991$ and $11 / 1992$, respectively). The P6 station 100 data (7/1992) were collected ca. 250 nautical miles $(463 \mathrm{~km})$ away $\left(32.5^{\circ} \mathrm{S}\right.$, $130^{\circ} \mathrm{W}$ ). The insert shows data from the bottom $2500 \mathrm{~dB}$ on an expanded scale. Both LV and AMS techniques were employed on the TUNES and Juno cruises while only AMS was used on P6. No systematic difference in techniques is evident for these data. 


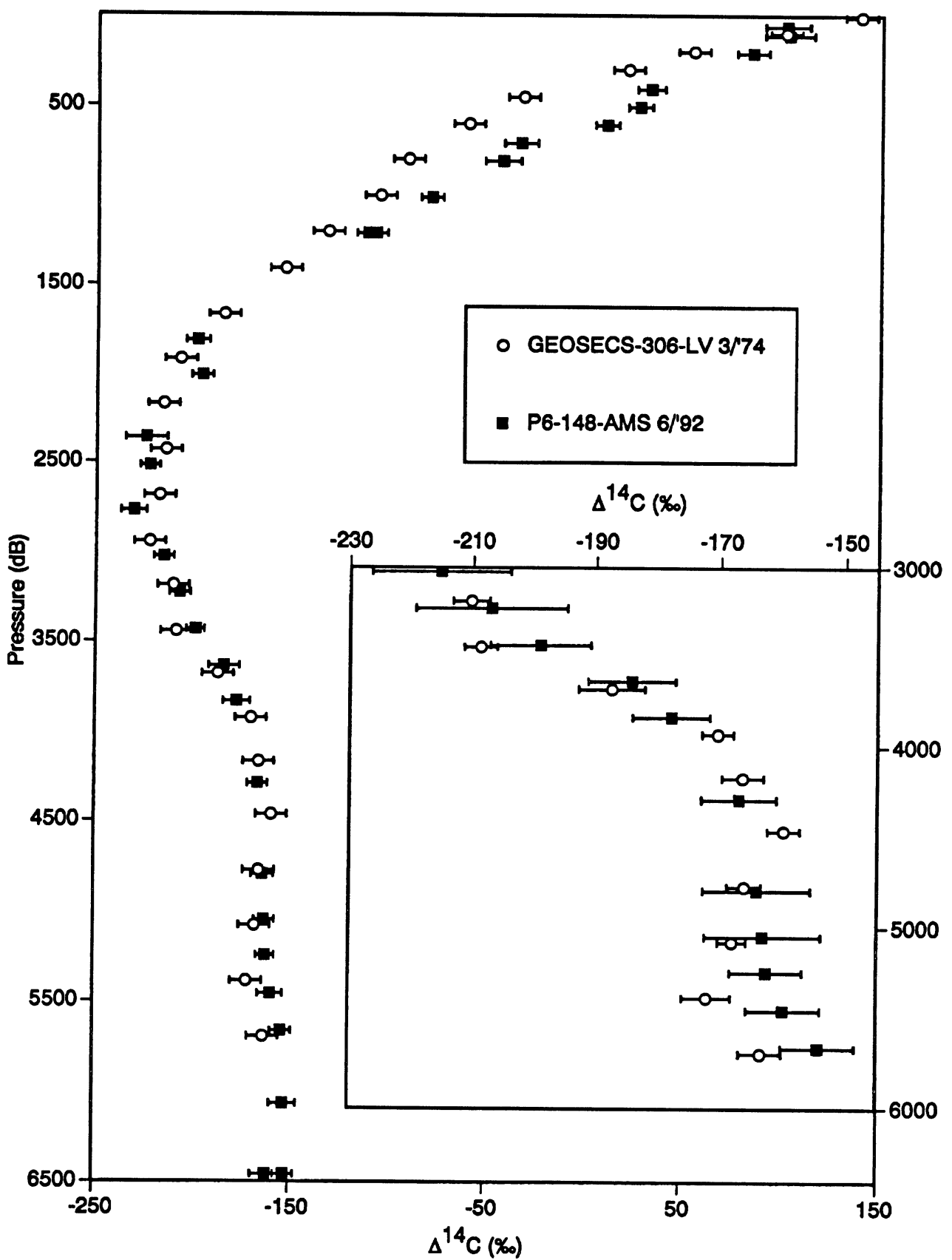

Fig. 3. Comparison of WOCE AMS (P6 station $\left.148,32.5^{\circ} \mathrm{S}, 163.6^{\circ} \mathrm{W}, 6 / 1992\right)$ results with GEOSECS (station 306 , $\left.32.5^{\circ} \mathrm{S}, 165.2^{\circ} \mathrm{W}, 3 / 1974\right) \mathrm{LV}$ results. (Error bars represent the 2-o range). Data from the $3000-6000 \mathrm{~dB}$ range is shown on an expanded scale in the insert. The invasion of bomb-produced ${ }^{14} \mathrm{C}$ during the time interval between the expeditions is clearly evident in the $250-1250 \mathrm{~dB}$ range. The deepwater values for the two stations appear to be the same. A statistical analysis of the entire WOCE data set will be required to determine if the slight difference $c a .5500 \mathrm{~dB}$. is significant. If real, the direction of the bottom water difference is consistent with a very small addition of bomb-produced ${ }^{14} \mathrm{C}$ over the time interval. 
newer AMS technique are comparable to the WOCE LV data as well as to the historical data. The combined WOCE data set is approximately an order of magnitude larger than all prior measurements in the Pacific combined.

\section{ACKNOWLEDGMENTS}

The author's portion of this work was supported by National Science Foundation grants OCE9002485 and OCE-9120306. Both of these grants were supplemented by National Oceanographic and Atmospheric Administration (NDAA) funds to cover the LV work. Additional NSF grants OCE-9002476 and OCE9207500 were received by P. Quay. NOSAMS was supported by NSF, and M. Stuiver and G. Östlund by NOAA grants to the University of Washington (JISAO Task 111-M and NA37RJ0200, respectively). Hydrography for the WOCE program was primarily done by the Scripps ODF group with assistance by the NOAA/PMEL and WHOI CTD groups. Special thanks is due to the individual chief scientists for each of the legs listed in Table 1 and to W. Nowlin, who acted as coordinator for the U.S. Pacific WOCE effort. In addition to R. Key and P. Quay, ${ }^{14} \mathrm{C}$ sampling in the Pacific was carried out by R. Rotter and G. McDonald from Princeton University and R. Sonnerup and S. King from the University of Washington.

\section{REFERENCES}

Broecker, W. S., and Olson, E. A. 1961 Lamont radiocarbon measurements VIII. Radiocarbon 3: 176-274.

Cohen, G. J., Hutton, D. L., von Reden, K. F., Osborne, E. A., Gagnon, A. R., McNichol, A. P. and Jones, G. A. 1994 Automated sample processing at the National Ocean Sciences AMS Facility. Nuclear Instruments and Methods in Physics Research 92B: 129-138.

Fonselius, S. and Östlund, H. G. 1959 Natural radiocarbon measurements on surface water from the North Atlantic and the Arctic Sea. Tellus 11: 77-82.

Gagnon, A. R., and Jones, G. A. 1993 AMS-graphite target production methods at the Woods Hole Oceanographic Institution during 1986-1991. Radiocarbon 35(2): 301-310.

Key, R. M. 1991 Radiocarbon. In WOCE Hydrographic Operations and Methods Manual, WOCE Hydrographic Program Office Technical Report. Woods Hole Oceanographic Institute, Woods Hole, Massachusetts.

1994 P16C TUNES-3 DQ report for large volume samples. WHP Report, December 1994. Ocean Tracer Lab, Department of Geological Science, Princeton University, Princeton, New Jersey.

1995 P17C TUNES-1 DQ report for large volume Samples. WHP Report, August 1995. Ocean Tracer Lab, Department of Geological Science, Princeton University, Princeton, New Jersey.

1996a P17C TUNES-1 final report for large volume samples. Ocean Tracer Laboratory Technical Report \#96-2, 1 July 1996. Princeton, New Jersey: 18 p.

1996b P17C TUNES-1 final report for AMS ${ }^{14} \mathrm{C}$ samples. Ocean Tracer Laboratory Technical Report \#96-3, 2 July 1996. Princeton, New Jersey: 9 p.

1996c P16S17S TUNES-2 final report for large vol- ume samples. Ocean Tracer Laboratory Technical Report \#96-4, 3 July 1996. Princeton, New Jersey: 14 p. 1996d P16S17S TUNES-2 final report for AMS ${ }^{14} \mathrm{C}$ samples. Ocean Tracer Laboratory Technical Report \#96-5, 5 July 1996. Princeton, New Jersey: 10 p.

1996e P16A17A Final report for large volume samples and $\Delta^{14} \mathrm{C}$ measurements. Ocean Tracer Laboratory Technical Report \#96-7, 7 July 1996. Princeton, New Jersey: 13 p.

1996f P17E19S Final report for large volume samples and $\Delta^{14} \mathrm{C}$ measurements. Ocean Tracer Laboratory Technical Report \#96-8, 8 July 1996. Princeton, New Jersey: $15 \mathrm{p}$.

1996g P6 final report for AMS ${ }^{14} \mathrm{C}$ samples. Ocean Tracer Laboratory Technical Report \#96-9, 9 July 1996. Princeton, New Jersey: 9 p.

1996h P19C Final report for large volume samples and $\Delta^{14} \mathrm{C}$ measurements. Ocean Tracer Laboratory Technical Report \#96-10, 10 July 1996. Princeton, New Jersey: $20 \mathrm{p}$.

1996i P17N Final report for large volume samples. Ocean Tracer Laboratory Technical Report \#96-11, 11 July 1996. Princeton, New Jersey: 21 p.

Key, R. M., Muus, D., and Wells, J. 1991 Zen and the art of Gerard barrel maintenance, WOCE Hydrographic Program Office Technical Report.

Key, R. M. and Quay, P. 1996 P16C TUNES-3 final report for AMS ${ }^{14} \mathrm{C}$ samples. Ocean Tracer Laboratory Technical Report \#96-6, 6 July 1996: 9 p.

Key, R. M., Quay, P. D., Jones, G. A., McNichol, A. P., von Reden, K. F. and Schneider, R. J. 1996 WOCE AMS radiocarbon I: Pacific Ocean results (P6, P16 and P17). Radiocarbon, this issue.

McNichol, A. P. and Jones, G. A. 1991 Measuring ${ }^{14} \mathrm{C}$ in 
seawater by Accelerator Mass Spectrometry. WOCE Hydrographic Operations and Methods manual, WOCE Report No. 68/91. WOCE Hydrographic Programme Office/Woods Hole Oceanographic Institution, Woods Hole, Massachusetts.

McNichol, A. P., Jones, G. A., Hutton, D. L., Gagnon, A. R., and Key, R. M. 1994 The rapid preparation of seawater $\Sigma \mathrm{CO}_{2}$ for radiocarbon analysis at the National Ocean Sciences AMS Facility. Radiocarbon 36(2): 237-246.

NOSAMS 1994a National Ocean Sciences AMS Facility Data Report \#94-091, Woods Hole Oceanographic Institution, Woods Hole, Massachusetts.

1994b National Ocean Sciences AMS Facility Data Report \#94-092, Woods Hole Oceanographic Institution, Woods Hole, Massachusetts.

1994c National Ocean Sciences AMS Facility Data Report \#94-093, Woods Hole Oceanographic Institution, Woods Hole, Massachusetts.

1995a, National Ocean Sciences AMS Facility Data Report \#95-030, Woods Hole Oceanographic Institution, Woods Hole, Massachusetts.

1995b, National Ocean Sciences AMS Facility Data Report \#95-052, Woods Hole Oceanographic Institution, Woods Hole, Massachusetts.

1995c, National Ocean Sciences AMS Facility Data Report \#95-066, Woods Hole Oceanographic Institution, Woods Hole, Massachusetts.

1996, National Ocean Sciences AMS Facility Data Report \#96-019, Woods Hole Oceanographic Institution, Woods Hole, Massachusetts.

Osborne, E. A., McNichol, A. P., Gagnon, A. R., Hutton, D. L., and Jones, G. A. 1994 Internal and external checks in the NOSAMS sample preparation laboratory for target quality and homogeneity. Nuclear Instruments and Methods in Physics Research B92: 158-161.

Östlund, G. 1992a Discoverer CGC 91 Cruise Radiocarbon Results, Tritium Laboratory Data Release \#92-15. University of Miami, R.S.M.A.S., Miami, Florida. 1992b WOCE Radiocarbon (Miami) Leg P17C, Tritium Laboratory Data Release \#92-83. University of Miami, R.S.M.A.S., Miami, Florida.

1994 WOCE Radiocarbon (Miami), Tritium Laboratory Data Release \#94-11. University of Miami, R.S.M.A.S., Miami, Florida.

1995 WOCE Radiocarbon (Miami) Remaining Sample Analyses, Tritium Laboratory Data Release \#95-39. University of Miami, R.S.M.A.S., Miami, Florida.

Östlund, H. G. and Stuiver, M. 1980 GEOSECS Pacific radiocarbon. Radiocarbon 22(1): 25-53.

Schneider, R. J., Jones, G. A., McNichol, A. P., von Reden, K. F., Elder, K. L., Huan, K. and Kessel, E. D. 1994 Methods for data screening, flagging and error analysis at the National Ocean Sciences AMS Facility. Nuclear Instruments and Methods in Physics Research 92B: 172-175.

Séguin, F. H., Schneider, R. J., Jones, G. A. and von Reden, K. F. 1994 Optimized data analysis for AMS radiocarbon dating. Nuclear Instruments and Methods in Physics Research 92B: 176-181.

Stuiver, M. 1980 Workshop on ${ }^{14} \mathrm{C}$ reporting. In Stuiver, M. and Kra, R. S., eds., Proceedings of the 10th International ${ }^{14} \mathrm{C}$ Conference. Radiocarbon 22(3): 964 966.

1994 WOCE Radiocarbon (Seattle), Quaternary Isotope Laboratory Data Report. University of Washington, Seattle.

Stuiver M., and Robinson, S. W. 1974 University of Washington GEOSECS North Atlantic carbon-14 results. Earth and Planetary Science Letters 23: 87-90.

Stuiver, M., Robinson, S. W., Östlund, H. G. and Dorsey, H. G. 1974 Carbon-14 calibration between the University of Washington and the University of Miami GEOSECS laboratories. Earth and Planetary Science Letters 23: 65-68.

Stuiver, M., Östlund, H. G., Key, R. M. and Reimer, P. J. 1996 Large-volume WOCE radiocarbon sampling in the Pacific Ocean. Radiocarbon, this issue. 